\title{
JAMES D. HOGG, IN MEMORIAM
}

JIM A. WEDGWOOD, 610 Leslie Ave., Saskatoon, Sask.

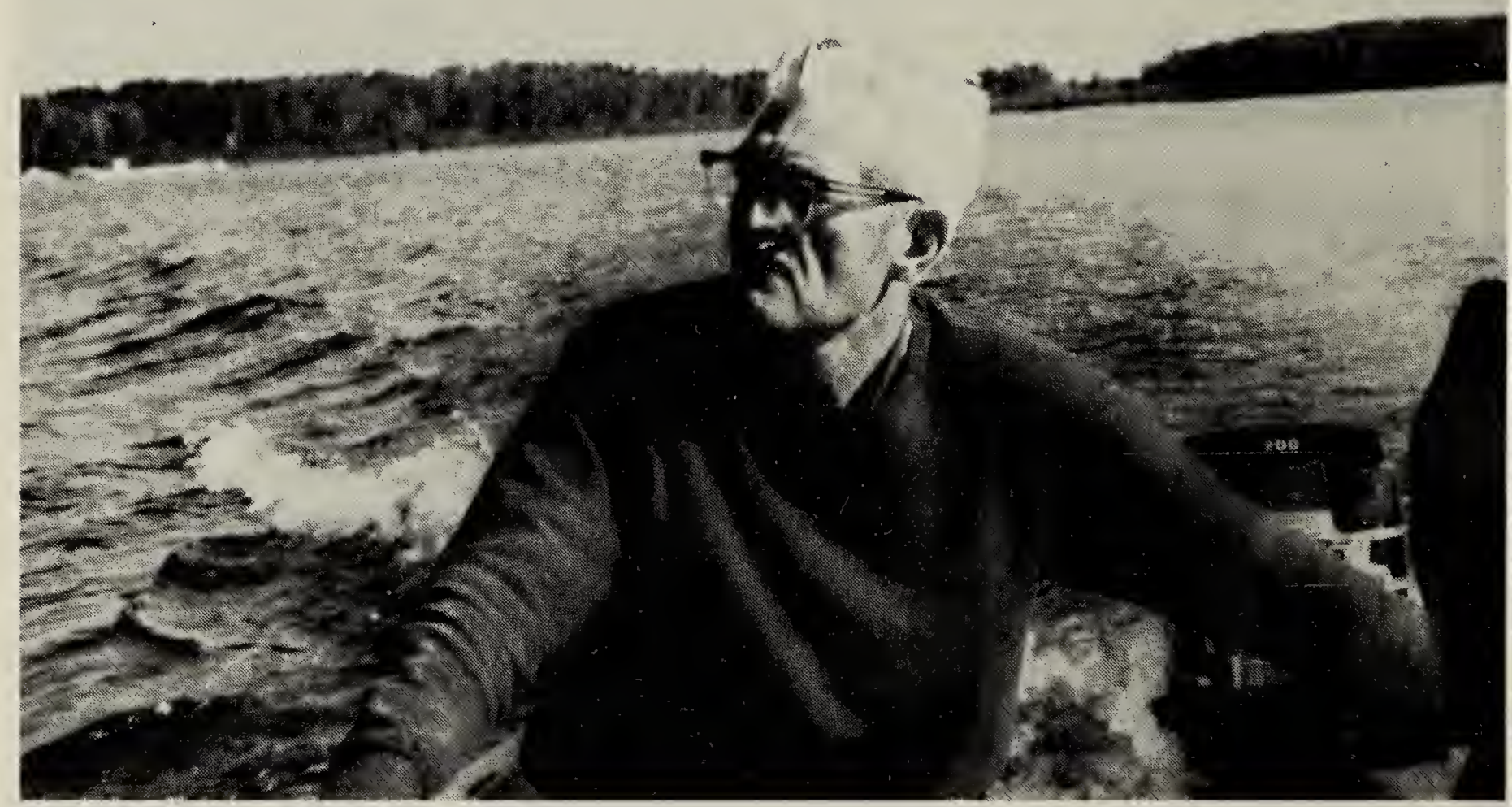

Jim Hogg at Lac La Ronge.

Mary Shadick

Jim Hogg of Saskatoon, a long time member of the Society, died on June 19 th.

Born in Scotland, Jim was 7 years old when his family came to Saskatoon, his home until his death. An electrician by trade, he joined the University of Saskatchewan's maintenance crew in 1937, eventually becoming Director of Maintenance. He retired 2 years ago.

Though naturally friendly and easy to meet, he was quiet about himself. It took a while to get to know him. Few of his acquaintenances in natural history circles knew he was once a star athlete, in 1924 setting a provincial high school track record for the mile race, a record which stood for a quarter of a century. When it was finally broken he made the official presentation of the ribbon to the winner.

As a young man Jim was active in
Boy Scout work, serving as leader for the Rovers. This was a special delight to him because of the opportunities to be out of doors on camping trips. He liked to tell of the time they camped at Beaver Creek and one dark night the boys became edgy upon seeing a ghostly light among the trees - until Jim showed them that the eerie luminescence was from a fungus.

Avid campers, the Hoggs tented all over Western Canada and the States. They used to paint on the walls of their tent the names and dates of places where they camped. When the old tent was finally retired, its walls were covered with inscriptions. The Hoggs were among the first to make the circuit by water of the lakes in the back country of Prince Albert National Park, in 1936.

Jim and his wife Grace joined the Society in the early fifties and became 
familiar figures at the annual Summer Meets. They missed only two of these outings in 22 years. He was in the nucleus of local naturalists from which the Saskatoon Natural History Society evolved. A charter member, he served on the executive and was often a field trip leader. Jim's Bluebird Hike each spring became a local institution. He could be counted on in other ways too - helping with arrangements, forming work parties, contributing to programs - the conscientious rock-steady member at the core of the well-being of any society.

Many members of the provincial and local societies will recall seeing his nature slides. However, his photographic artistry was not limited to nature studies. A first-rate photographer, Jim had been continuously active in the Saskatoon Camera Club since 1941, being one of its past presidents and an honorary life member. He always placed well in Club competitons and often took awards. However, he had established a reputation in black-and-white photography long before then. While still in his twenties he had several of his works accepted in exhibition salons in the United States.

Jim was a good observer of birds and contributed much to the bird lore of the Saskatoon area. On two occasions he discovered species not previously recorded in the district.

His greatest contribution, however, was introducing others to bird watching, including the author of this memorial. The groups he led - for 20 years - on the Christmas and Mayday Bird Counts were invariably the largest of all the groups, people simply appreciating being with Jim for the day.

Jim didn't express in words what nature meant to him or his beliefs about conservation or his understanding of ecology. He didn't have to. His empathy with the natural world was somehow transmitted to others. He made one aware how often one observes without really seeing or feeling. I count myself fortunate to have known a man as tuned to his surroun- dings as Jim Hogg was. Two instances among many stand out in my mind: on a hiking trip in the north woods one December, watching Canada Jays and crossbills fly down and feed out of his hand as if it were the most natural thing on earth; and on a pack horse trip in the Rockies, standing on a mountain ridge with Jim, and realizing that he too felt the immensity of the scene force some of the wonder of creation into the consciousness. Words were not needed.

It was while leading a field trip that Jim died, on the banks of Eagle Creek, where he loved to be - outdoors.

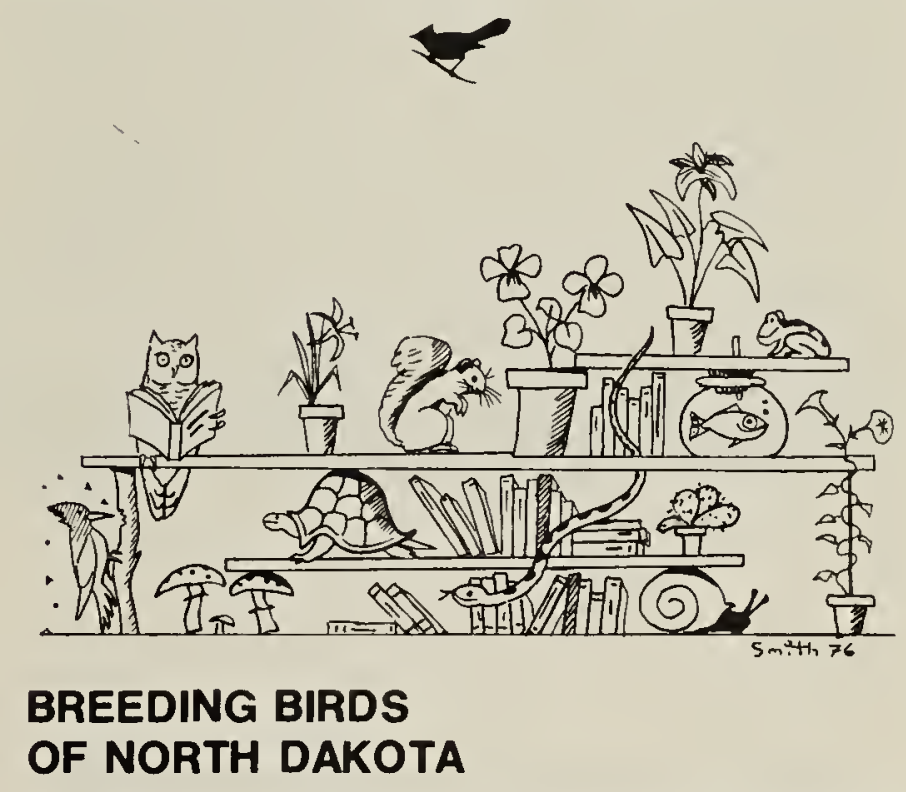

By Robert E. Stewart, Tri-College Center for Environmental Studies, Fargo, N.D. 1975. 295 pp. $\$ 18.50$ U.S.

This is a truly magnificent book. Chan Robbins correctly states in the introduction that "No other state can boast so complete a picture of the distribution and abundance of breeding birds as this volume now supplies." This book is remarkable in its thorough historical research, intensive fieldwork, superb ecological correlation, beautiful photographs and maps, and thorough bibliographic citation.

Stewart's fieldwork covered the state for more than 10 years, with a special attempt to count every pair of breeding birds in 130 representative but randomly selected quarter sections, three times during the 1967 breeding season. Stewart discusses the typical bird life of 9 different ecologic regions (e.g., Missouri Coteau and 